\title{
Statistical optimization of process parameters for exopolysaccharide production by Aureobasidium pullulans using sweet potato based medium
}

\author{
Sethuraman Padmanaban ${ }^{1}$ - Nagarajan Balaji ${ }^{1}$ - Chandrasekaran Muthukumaran ${ }^{2}$. \\ Krishnamurthi Tamilarasan ${ }^{1,3}$
}

Received: 28 October 2014/ Accepted: 12 May 2015/Published online: 2 June 2015

(C) The Author(s) 2015. This article is published with open access at Springerlink.com

\begin{abstract}
Statistical experimental designs were applied to optimize the fermentation medium for exopolysaccharide (EPS) production. Plackett-Burman design was applied to identify the significance of seven medium variables, in which sweet potato and yeast extract were found to be the significant variables for EPS production. Central composite design was applied to evaluate the optimum condition of the selected variables. Maximum EPS production of $9.3 \mathrm{~g} /$ $\mathrm{L}$ was obtained with the predicted optimal level of sweet potato $10 \%$, yeast extract $0.75 \%, 5.5 \mathrm{pH}$, and time $100 \mathrm{~h}$. The determined $\left(R^{2}\right)$ value was 0.97 , indicating a good fitted model for EPS production. Results of this study showed that sweet potato can be utilized as a low-cost effective substrate for pullulan production in submerged fermentation.
\end{abstract}

Keywords Sweet potato - Exopolysaccharide - Response surface methodology · Central composite design

Krishnamurthi Tamilarasan

tamilbio@gmail.com

1 Department of Biotechnology, Madha Engineering College, Kundrathur, Chennai 600069, Tamilnadu, India

2 Department of Industrial Biotechnology, Government College of Technology, Coimbatore 641013, Tamilnadu, India

3 Department of Chemical Engineering, School of Bioengineering, SRM University, Kattankulathur, Chennai 603203, Tamilnadu, India

\section{Introduction}

Biopolymers produced by a wide variety of microorganisms which are generally water soluble gums having novel and unique physical properties. Polysaccharides have found a wide range of applications in the food, pharmaceutical, and other industries. Typical industrial uses of EPS are as food coatings and packaging material due to its good film-forming properties similar to those of polyvinyl alcohol. Pullulan is used as an adhesive in the form of paste with water, as a construction material with fibers similar in strength and elasticity to those in nylon and as a bulking agent and stabilizer for tablets in the pharmaceutical industry (Deshpande et al. 1992). Many researchers have optimized the production conditions for exopolysaccharide (EPS) in submerged culture by Fomes fomentarius (Chen et al. 2008), Tremella fuciformis (Cho et al. 2006), Pholiota squarrosa (Wang et al. 2004), Agrocybe cylindracea (Kim et al. 2005), Collybia maculate (Lim et al. 2004), Cordyceps jiangxiensis (Xiao et al. 2004), Cordyceps militaris (Kim et al. 2003), Aureobasidium pullulans (Moubasher and Wahsh 2014), and Tremella mesenterica (De Baets et al. 2002).

For a wide application, the cost of medium components is one of the main factors determining the economics of a process. In the literature, several agro-based products were utilized as low-cost substrate in the medium for economic production of pullulan through fermentation process (Srikanth et al. 2014; Sharmila et al. 2013a; Goksungur et al. 2011; Wu et al. 2009). In this study, sweet potato was used as an alternative low-cost carbon source for pullulan production.

Statistical experimental designs such as Plackett-Burman (BP) design and response surface methodology (RSM) are successfully employed to screen and optimize the process parameters in bioprocess field (Sharmila et al. 
2013b). RSM, an experimental strategy for seeking the optimum conditions for a multivariable system, is a much more efficient technique for optimization (Alok et al. 2013; Aarthi and Karna 2012; Baskar and Renganathan 2012; Zhou et al. 2013; Mayur et al. 2013). Central composite design (CCD) is widely employed for bioprocess optimization studies and it can give information about the interaction between variables, provide information necessary for design and process optimization. The aim of the present work is to screen and optimize the process variables for EPS production from A. pullulans MTCC 2195 using statistical techniques.

\section{Materials and methods}

\section{Microorganism and chemicals}

Aureobasidium pullulans MTCC 2195 was obtained from Microbial Type Culture Collection and Gene Bank, Institute of Microbial Technology (IMTECH), India. Sucrose and yeast extract purchased from HiMedia Laboratories Pvt Ltd, (Mumbai, India). $\mathrm{KH}_{2} \mathrm{PO}_{4}, \mathrm{MgSO}_{4} \cdot 7 \mathrm{H}_{2} \mathrm{O}$, and $\mathrm{NaCl}$ were purchased from Qualigens fine chemicals. $\mathrm{ZnSO}_{4} \cdot 7 \mathrm{H}_{2} \mathrm{O}$ and $\mathrm{CuSO}_{4} \cdot 5 \mathrm{H}_{2} \mathrm{O}$ were procured from Loba Chemie. All the media components were of analytical grade, and solvents were purchased from Merck.

\section{Inoculum and substrate preparation}

Inoculum was prepared by transferring a loopful of stock culture to the growth medium. Growth medium contains (w/v) sucrose $5 \%$, yeast extract $0.2 \%, \mathrm{KH}_{2} \mathrm{PO}_{4} 0.5 \%$, $\mathrm{MgSO}_{4} .7 \mathrm{H}_{2} \mathrm{O} 0.02 \%$, and $\mathrm{NaCl} 0.1 \%$. The cultivation was performed at $35^{\circ} \mathrm{C}$ for 3 days. Sweet potato was obtained from the local market in Chennai. It was ground into powder with a blender and passed through a sieve (80/ 100 mesh size) to remove large-sized particles, and the fine sweet potato powder was used for further studies.

\section{Fermentation conditions}

Aureobasidium pullulans was inoculated in a production media containing (w/v) sweet potato $10 \%$, yeast extract $0.5 \%,\left(\mathrm{NH}_{4}\right)_{2} \mathrm{SO}_{4} 0.4 \%, \mathrm{NaNO}_{3} 0.4 \%, \mathrm{NaCl} 0.2 \%$, $\begin{array}{llll}\mathrm{KH}_{2} \mathrm{PO}_{4} \quad 0.2 \%, & \mathrm{MgSO}_{4} \cdot 7 \mathrm{H}_{2} \mathrm{O} \quad 0.2 \%, & \mathrm{ZnSO}_{4} \cdot 7 \mathrm{H}_{2} \mathrm{O}\end{array}$ $0.05 \%$, and $\mathrm{CuSO}_{4} \cdot 5 \mathrm{H}_{2} \mathrm{O} 0.05 \%$, of pH 5.5. Fermentation at $35{ }^{\circ} \mathrm{C}$ for $120 \mathrm{~h}$ under shaking at $120 \mathrm{rpm}$ with $2 \%$ inoculum was performed. Five milliliters of the culture was taken at $120 \mathrm{~h}$, and the culture was centrifuged at $14,000 \times g, 4^{\circ} \mathrm{C}$ for $20 \mathrm{~min}$. The culture supernatant was used for EPS precipitation.

\section{Estimation of exopolysaccharide}

Supernatant fluid was mixed with three volumes of $95 \%$ ethanol, stirred vigorously, and incubated at $4{ }^{\circ} \mathrm{C}$ for $24 \mathrm{~h}$ to precipitate the polysaccharide, which was separated by centrifugation at $14,000 \times g$ for $20 \mathrm{~min}$ and dried at $90{ }^{\circ} \mathrm{C}$ for $12 \mathrm{~h}$ (Wu et al. 2009). The EPS concentration was expressed as milligram per milliliter.

\section{Plackett-Burman design}

Plackett-Burman design is used to screen the significant media components from large number of variables with minimum number of experiments (Plackett and Burman, 1946). This is a very economical factorial design with the run number a multiple of four and comprises two-level

Table 1 Plackett-Burman experimental design for screening of media components for EPS production

\begin{tabular}{|c|c|c|c|c|c|c|c|c|}
\hline \multirow[t]{2}{*}{ Std. order } & \multicolumn{7}{|c|}{ Media components, (w/v) $(\%)$} & \multirow[t]{2}{*}{ EPS $(g / L)$} \\
\hline & $\mathrm{A}$ & $\mathrm{B}$ & $\mathrm{C}$ & $\mathrm{D}$ & $\mathrm{E}$ & $\mathrm{F}$ & G & \\
\hline 1 & 15 & 0.5 & 0.6 & 0.3 & 0.1 & 0.1 & 0.3 & 7.2 \\
\hline 2 & 15 & 1.0 & 0.3 & 0.6 & 0.1 & 0.1 & 0.1 & 7.5 \\
\hline 3 & 5 & 1.0 & 0.6 & 0.3 & 0.3 & 0.1 & 0.1 & 4.0 \\
\hline 4 & 15 & 0.5 & 0.6 & 0.6 & 0.1 & 0.3 & 0.1 & 6.8 \\
\hline 5 & 15 & 1.0 & 0.3 & 0.6 & 0.3 & 0.1 & 0.3 & 8.0 \\
\hline 6 & 15 & 1.0 & 0.6 & 0.3 & 0.3 & 0.3 & 0.1 & 9.0 \\
\hline 7 & 5 & 1.0 & 0.6 & 0.6 & 0.1 & 0.3 & 0.3 & 4.0 \\
\hline 8 & 5 & 0.5 & 0.6 & 0.6 & 0.3 & 0.1 & 0.3 & 2.0 \\
\hline 9 & 5 & 0.5 & 0.3 & 0.6 & 0.3 & 0.3 & 0.1 & 3.0 \\
\hline 10 & 15 & 0.5 & 0.3 & 0.3 & 0.3 & 0.3 & 0.3 & 6.8 \\
\hline 11 & 5 & 1.0 & 0.3 & 0.3 & 0.1 & 0.3 & 0.3 & 4.5 \\
\hline 12 & 5 & 0.5 & 0.3 & 0.3 & 0.1 & 0.1 & 0.1 & 3.0 \\
\hline
\end{tabular}


Table 2 Statistical analysis of Plackett-Burman design on EPS production

\begin{tabular}{lllcrcr}
\hline Variables & Lower level $(-1)$ & Higher level $(+1)$ & Main effect & $t$ value & $p$ value & Confidence level $(\%)$ \\
\hline Sweet potato, $\left(\mathrm{X}_{1}\right)$ & 5 & 15 & 4.13 & 16.35 & $<0.001$ & 99.9 \\
Yeast extract, $\left(\mathrm{X}_{2}\right)$ & 0.5 & 1.0 & 1.36 & 5.41 & 0.006 & 99.4 \\
$\mathrm{NH}_{4} \mathrm{SO}_{4},\left(\mathrm{X}_{3}\right)$ & 0.3 & 0.6 & 0.03 & 0.13 & 0.901 & 09.9 \\
$\mathrm{NaNO}_{3},\left(\mathrm{X}_{4}\right)$ & 0.3 & 0.6 & -0.53 & -2.11 & 0.102 & 89.8 \\
$\mathrm{NaCl},\left(\mathrm{X}_{5}\right)$ & 0.1 & 0.3 & -0.03 & -0.13 & 0.901 & 09.9 \\
$\mathrm{KH}_{2} \mathrm{PO}_{4},\left(\mathrm{X}_{6}\right)$ & 0.1 & 0.3 & 0.40 & 1.58 & 0.189 & 81.1 \\
$\mathrm{MgSO}_{4},\left(\mathrm{X}_{7}\right)$ & 0.1 & 0.3 & -0.13 & -0.53 & 0.626 & 37.4 \\
\hline
\end{tabular}

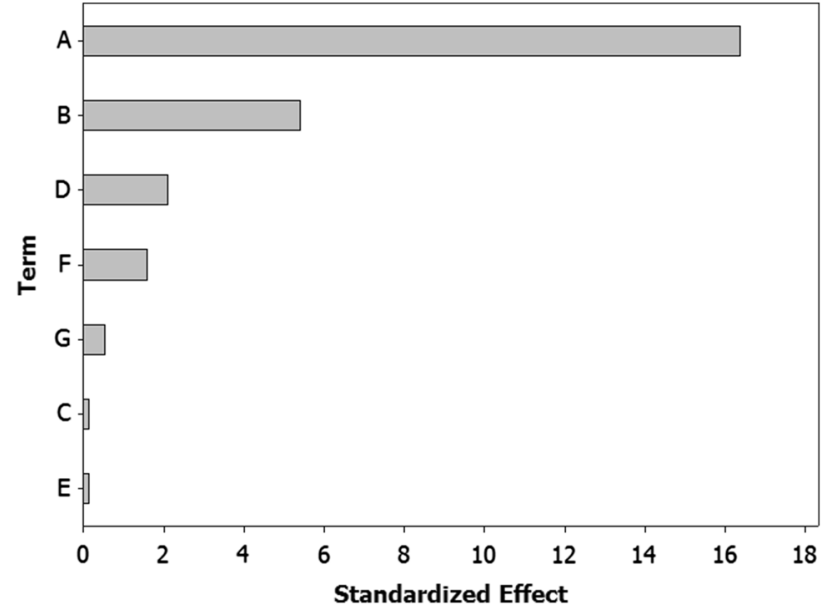

Fig. 1 Pareto plot for Plackett-Burman parameter estimates for seven medium components. $A$ Sweet potato, $B$ yeast extract, $C \mathrm{NH}_{4} \mathrm{SO}_{4}, D \mathrm{NaNO}_{3}, E \mathrm{NaCl}, F \mathrm{KH}_{2} \mathrm{PO}_{4}$, and $G \mathrm{MgSO}_{4}$

screening designs (Cupul et al. 2014). This design is extremely useful in screening importance of the factors affecting the production of polymer (Wang et al. 2014). This model describes no interaction among the factors that influences EPS production. Twelve experimental run was carried out to study the effect of seven medium components for EPS production. All the factors are prepared at two levels " -1 " for low level and " +1 " for high level. The seven factors, sweet potato, yeast extract, $\mathrm{NH}_{4} \mathrm{SO}_{4}$, $\mathrm{NaNO}_{3}, \mathrm{NaCl}, \mathrm{KH}_{2} \mathrm{PO}_{4}$, and $\mathrm{MgSO}_{4}$, were studied on EPS production. $\mathrm{ZnSO}_{4} \cdot 7 \mathrm{H}_{2} \mathrm{O}$ and $\mathrm{CuSO}_{4} \cdot 5 \mathrm{H}_{2} \mathrm{O}$ were used as dummy variables. Table 1 shows the factors considered for investigation, and twelve experimental runs were carried out for EPS production. The fermentation was carried out for $120 \mathrm{~h}$ at $35^{\circ} \mathrm{C}$ and $120 \mathrm{rpm}$.

\section{Central composite design}

Central composite design developed by the Minitab 14 software was used to optimize the condition of the screened variables sweet potato, yeast extract, $\mathrm{pH}$, and time. Other components of the medium were (w/v) $\left(\mathrm{NH}_{4}\right)_{2} \mathrm{SO}_{4} 0.4 \%$,
Table 3 CCD matrix of independent variables used in RSM with corresponding experimental and predicted values of EPS production

\begin{tabular}{|c|c|c|c|c|c|c|}
\hline \multirow[t]{2}{*}{ Std. order } & \multirow[t]{2}{*}{ A } & \multirow[t]{2}{*}{ B } & \multirow[t]{2}{*}{$\mathrm{C}$} & \multirow[t]{2}{*}{$\mathrm{D}$} & \multicolumn{2}{|l|}{ EPS (g/L) } \\
\hline & & & & & Experimental & Predicted \\
\hline 1 & 5 & 0.50 & 4.5 & 80 & 5.2 & 4.8 \\
\hline 2 & 15 & 0.50 & 4.5 & 80 & 7.0 & 7.1 \\
\hline 3 & 5 & 1.00 & 4.5 & 80 & 4.2 & 4.6 \\
\hline 4 & 15 & 1.00 & 4.5 & 80 & 7.5 & 7.3 \\
\hline 5 & 5 & 0.50 & 6.5 & 80 & 3.5 & 3.9 \\
\hline 6 & 15 & 0.50 & 6.5 & 80 & 8.2 & 8.0 \\
\hline 7 & 5 & 1.00 & 6.5 & 80 & 3.5 & 3.7 \\
\hline 8 & 15 & 1.00 & 6.5 & 80 & 8.3 & 8.1 \\
\hline 9 & 5 & 0.50 & 4.5 & 120 & 3.0 & 3.4 \\
\hline 10 & 15 & 0.50 & 4.5 & 120 & 5.0 & 4.8 \\
\hline 11 & 5 & 1.00 & 4.5 & 120 & 5.1 & 5.2 \\
\hline 12 & 15 & 1.00 & 4.5 & 120 & 7.1 & 6.9 \\
\hline 13 & 5 & 0.50 & 6.5 & 120 & 3.8 & 3.9 \\
\hline 14 & 15 & 0.50 & 6.5 & 120 & 7.2 & 7.0 \\
\hline 15 & 5 & 1.00 & 6.5 & 120 & 5.4 & 5.6 \\
\hline 16 & 15 & 1.00 & 6.5 & 120 & 8.8 & 9.1 \\
\hline 17 & 0 & 0.75 & 5.5 & 100 & 3.2 & 2.6 \\
\hline 18 & 20 & 0.75 & 5.5 & 100 & 7.9 & 8.4 \\
\hline 19 & 10 & 0.25 & 5.5 & 100 & 5.0 & 5.0 \\
\hline 20 & 10 & 1.25 & 5.5 & 100 & 7.1 & 6.9 \\
\hline 21 & 10 & 0.75 & 3.5 & 100 & 4.8 & 4.9 \\
\hline 22 & 10 & 0.75 & 7.5 & 100 & 6.4 & 6.2 \\
\hline 23 & 10 & 0.75 & 5.5 & 60 & 6.7 & 6.7 \\
\hline 24 & 10 & 0.75 & 5.5 & 140 & 6.5 & 6.3 \\
\hline 25 & 10 & 0.75 & 5.5 & 100 & 9.1 & 8.9 \\
\hline 26 & 10 & 0.75 & 5.5 & 100 & 8.9 & 8.9 \\
\hline 27 & 10 & 0.75 & 5.5 & 100 & 8.8 & 8.9 \\
\hline 28 & 10 & 0.75 & 5.5 & 100 & 8.2 & 8.9 \\
\hline 29 & 10 & 0.75 & 5.5 & 100 & 9.3 & 8.9 \\
\hline 30 & 10 & 0.75 & 5.5 & 100 & 8.9 & 8.9 \\
\hline 31 & 10 & 0.75 & 5.5 & 100 & 9.0 & 8.9 \\
\hline
\end{tabular}

$\mathrm{NaNO}_{3} 0.4 \%, \mathrm{NaCl} 0.2 \%, \mathrm{KH}_{2} \mathrm{PO}_{4} 0.2 \%, \mathrm{MgSO}_{4} .7 \mathrm{H}_{2} \mathrm{O}$ $0.2 \%, \mathrm{ZnSO}_{4} \cdot 7 \mathrm{H}_{2} \mathrm{O} 0.05 \%$, and $\mathrm{CuSO}_{4} \cdot 5 \mathrm{H}_{2} \mathrm{O} 0.05 \%$ maintained as constant. Each factor in the design was 
studied at three levels. The minimum and maximum range of variables investigated and their values in actual and coded form are listed in Table 2. Experimental design includes 31 runs, and fermentation was carried out separately for each with replicates. The EPS concentration was taken as the dependent variable or response (Y). Regression analysis was performed on the data obtained. This resulted in an empirical model that related the response measured to the independent variables of the experiment. For any system, the model equation is represented as

$Y=A_{0}+\sum A_{i} X_{i}+\sum A_{i} X_{i}^{2}+\sum A_{i j} X_{i} X_{j}$,

where $Y$ is the predicted response, $A_{0}$ the intercept, $A_{i}$ the linear coefficient, and $A_{i j}$ is the interaction coefficient. An analysis of variance (ANOVA) was performed, and threedimensional response surface curves were plotted by Minitab 14 software to study the interaction among these factors.

\section{Results and discussion}

\section{Screening of media components for optimization process}

Seven factors of media components were examined in the Plackett-Burman design experiments with twelve different trials, and maximum EPS production was obtained for trial number 6 , while the lowest production was obtained for trial number 8 . The regression coefficients, $t$ value, and confidence level are given in Table 2. The media components showed both positive and negative effects on EPS production. Statistical analysis ( $t$ values) demonstrated that sweet potato and yeast extract had significant positive influences on the EPS production with main effects of 4.13 and 1.36 , respectively. The media components namely sweet potato (A) and yeast extract (B) were found to increase on EPS production at their high level. Whereas the media components namely $\left(\mathrm{NH}_{4}\right)_{2} \mathrm{SO}_{4}(\mathrm{C}), \mathrm{NaNO}_{3}(\mathrm{D}), \mathrm{NaCl}(\mathrm{E}), \mathrm{K}_{2} \mathrm{HPO}_{4}(\mathrm{~F})$, and $\mathrm{MgSO}_{4}(\mathrm{G})$ were found to decrease the EPS production at their higher level.

With the calculated $\mathrm{p}$ values at $90 \%$ confidence level being considered to be significant factor, sweet potato (confidence level $=100 \%$ ) and yeast extract (confidence level $=99.4 \%$ ) were identified as the significant media components for EPS production. Hence, the main effect of media components was also studied graphically using Pareto chart as shown in Fig. 1. In this result, sweet potato has the highest confidence level of $100 \%$, indicating that it is the key factor for EPS production.

Table 4 Analysis of variance of second-order Polynomial model for effect of variable on EPS production

\begin{tabular}{|c|c|c|c|c|c|c|}
\hline Sources & Coefficient & $\mathrm{DF}$ & SS & MS & $F$ value & $p$ value \\
\hline Model & 8.88 & 14 & 119.772 & 8.5551 & 52.66 & $<0.001^{*}$ \\
\hline Linear & & 4 & 58.462 & 14.6154 & 89.96 & $<0.001^{*}$ \\
\hline A:Sweet potato & 1.45 & 1 & 50.460 & 50.4600 & 310.59 & $<0.001^{*}$ \\
\hline B:Yeast extract & 0.46 & 1 & 5.227 & 5.2267 & 32.17 & $<0.001^{*}$ \\
\hline C:pH & 0.32 & 1 & 2.535 & 2.5350 & 15.60 & $0.001 *$ \\
\hline D:Time & -0.1 & 1 & 0.240 & 0.2400 & 1.48 & 0.242 \\
\hline Square & & 4 & 51.372 & 12.8431 & 79.05 & $<0.001 *$ \\
\hline Sweet potato*sweet potato & -0.85 & 1 & 21.097 & 21.0967 & 129.86 & $<0.001^{*}$ \\
\hline Yeast extract*Yeast extract & -0.73 & 1 & 15.403 & 15.4031 & 94.81 & $<0.001^{*}$ \\
\hline $\mathrm{pH}^{*} \mathrm{pH}$ & -0.84 & 1 & 20.487 & 20.4872 & 126.10 & $<0.001 *$ \\
\hline Time*time & -0.59 & 1 & 10.172 & 10.1723 & 62.61 & $<0.001 *$ \\
\hline 2-Way interaction & & 6 & 9.938 & 1.6563 & 10.19 & $<0.001^{*}$ \\
\hline Sweet potato*yeast extract & 0.1 & 1 & 0.160 & 0.1600 & 0.98 & 0.336 \\
\hline Sweet potato*pH & 0.45 & 1 & 3.240 & 3.2400 & 19.94 & $<0.001^{*}$ \\
\hline Sweet potato*time & -0.24 & 1 & 0.902 & 0.9025 & 5.56 & $0.032 *$ \\
\hline Yeast extract*pH & -0.02 & 1 & 0.010 & 0.0100 & 0.06 & 0.807 \\
\hline Yeast extract*time & 0.48 & 1 & 3.802 & 3.8025 & 23.41 & $<0.001^{*}$ \\
\hline $\mathrm{pH} *$ time & 0.33 & 1 & 1.823 & 1.8225 & 11.22 & $0.004 *$ \\
\hline Error & & 16 & 2.599 & 0.1625 & & \\
\hline Lack-of-fit & & 10 & 1.891 & 0.1891 & 1.60 & 0.292 \\
\hline Pure error & & 6 & 0.709 & 0.1181 & & \\
\hline Total & & 30 & 122.371 & & & \\
\hline$R^{2}$ & 0.97 & & & & & \\
\hline$R_{(\text {adj) }}^{2}$ & 0.96 & & & & & \\
\hline
\end{tabular}

* Significant model terms $(p<0.005)$ 
Fig. 2 Contour plots showing the combined effect of the medium variables (sweet potato, yeast extract, $\mathrm{pH}$, and time) on EPS production by Aureobasidium pullulans
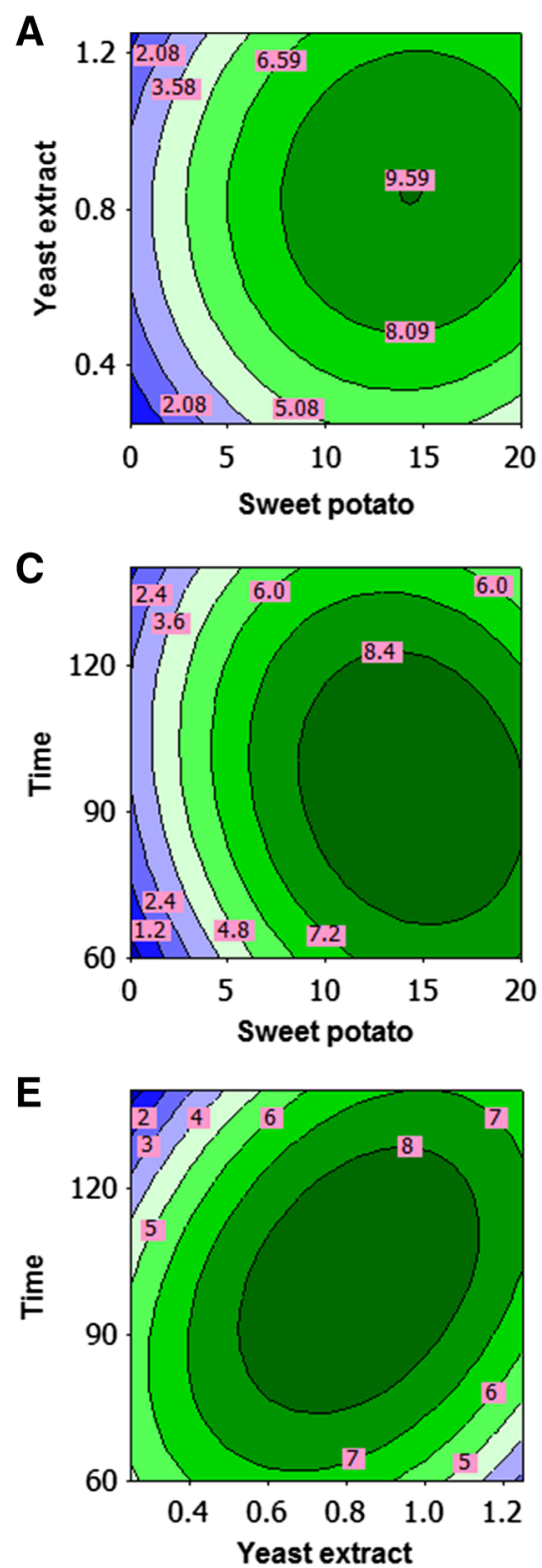
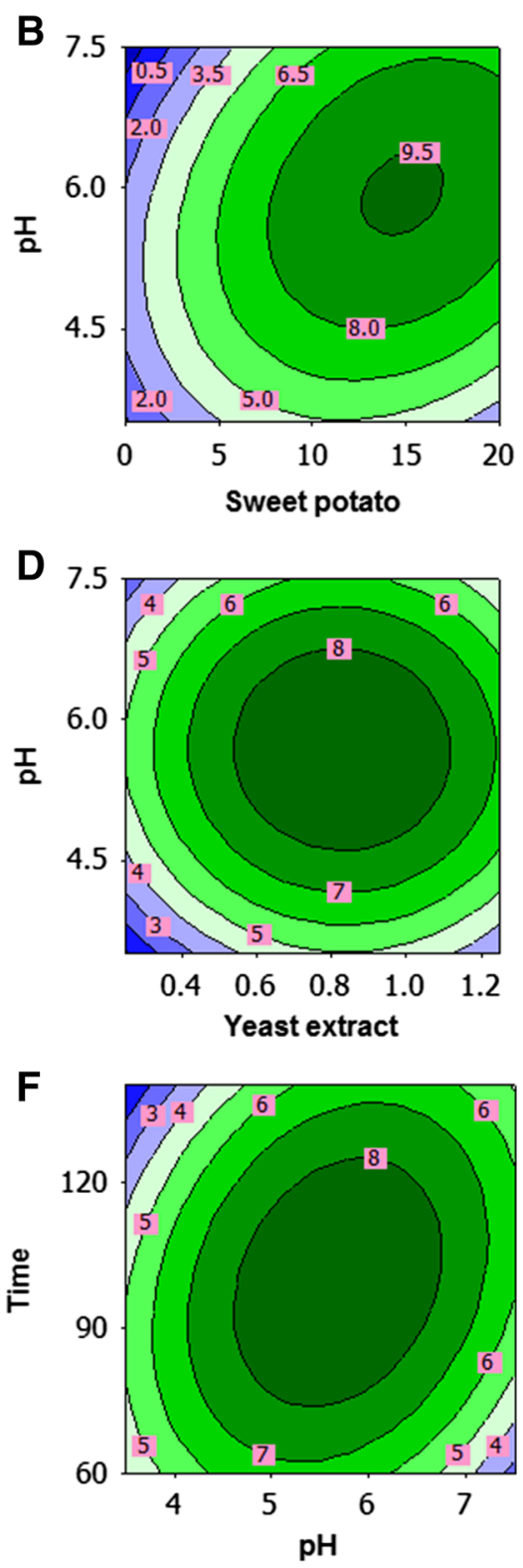

\section{Media optimization using central composite design}

The final medium optimization and interaction amongst the screened factors were studied using CCD. All the experiments were carried out in replicates, and average EPS given in Table 3 was subjected to multiple linear regression analysis. The effect of sweet potato, yeast extract, $\mathrm{pH}$, and time for EPS production was described in the form of second-order polynomial model in coded units (Eq. 2).

$$
\begin{aligned}
E P S(\mathrm{~g} / \mathrm{L})= & 8.88+1.45 \mathrm{~A}+0.46 \mathrm{~B}+0.32 \mathrm{C} \\
& -0.1 \mathrm{D}-0.85 A^{2}-0.73 B^{2}-0.84 C^{2} \\
& -0.59 D^{2}+0.10 \mathrm{AB}+0.45 \mathrm{AC} \\
& -0.24 \mathrm{AD}-0.02 \mathrm{BC}+0.48 \mathrm{BD}+0.33 \mathrm{CD} .
\end{aligned}
$$

The student's $t$ test and $F$-test were performed to determine the significance of the model. The residuals analysis was performed to validate the model at $95 \%$ confidence level. In this model, the $R^{2}$ value of 0.979 indicated that the response model can explain $97.9 \%$ of the total variations. In general, a regression model having an $R^{2}$ value higher than 0.9 is considered to have a very high correlation (Haaland 1989). The value of the adjusted determination coefficient $\left(R_{\text {adj }}^{2}=96 \%\right)$ was also high enough to indicate the significance of the model. The model fitted well with EPS production, and the optimal values from the model were justified $(p<0.001)$. The ANOVA results given in Table 4 indicate that the linear and square terms in second-order polynomial model (Eq. 2) were highly significant $(p<0.005)$ and adequate to represent the relationship between EPS production. 
The 3D response surface or contour plots were employed to determine the interaction of the fermentation conditions and the optimum levels for EPS production. The shape of the contour plot is used to identify the interaction of variables. Strong interaction exists if contour lines are elliptical in shape, and no interaction is observed if contour lines are circular. The mutual effect of sweet potato and yeast extract is shown in Fig. 2a. Maximum EPS production was obtained at the middle level of the variables and there was no interaction between the variables as contour lines are circular in shape. Figure $2 b$ shows the combined effect of sweet potato and $\mathrm{pH}$ on the response, and a significant interaction exists between sweet potato and $\mathrm{pH}$. The amylase enzyme synthesized by A. pullulans strain can degrade the sweet potato starch into simple carbohydrate molecules and be utilized for pullulan production as reported in previous studies (Manitchotpisit et al. 2011; Saha and Bothast 1993). As can be observed from Fig. 2c, EPS level increases as the time and sweet potato concentration increase till an optimal point is reached and EPS production decreases with further increase of time. Figure $2 \mathrm{~d}$ shows that high and low level of yeast extract and $\mathrm{pH}$ have no significant effect on the EPS production and increased production was observed at middle level of yeast extract with $\mathrm{pH}$. The interaction effect of yeast extract and time on EPS production is shown in Fig. 2e, while other factors were fixed as a constant. It was observed that the EPS production was reduced at low and high level, whereas increases towards middle level of yeast extract and time. Yeast extract in the production medium is essential nutrient to switch the morphological character (mycelial growth) of A. pullulans for pullulan synthesis. Figure $2 \mathrm{f}$ shows that strong interaction was observed between $\mathrm{pH}$ and time on EPS production as the contour is elliptical and maximum level was observed at middle level of $\mathrm{pH}$ and time. In other reports, optimal conditions for polymer production were obtained at an initial pH of 5.0 (Vijayendra et al. 2001), 6.5 (Roukas and Biliaderis 1995), and 7.5 (Auer and Seviour 1990). The different optimal initial $\mathrm{pH}$ values reported in the literature may be due to the different strains, compositions of fermentation media, and culture conditions used in those studies. Maximum EPS of $9.3 \mathrm{~g} / \mathrm{L}$ obtained in this study has good agreement with the results reported by Moubasher and Wahsh (2014). In contrast to our results, maximum pullulan yield was obtained with sweet potato starch and hydrolysed potato starch waste as reported earlier (Goksungur et al. 2011; Wu et al. 2009). The variation in pullulan production may be due to type of A. pullulans strain, medium components, and process conditions.

\section{Conclusion}

Statistical optimization was confirmed to be a powerful method for the optimization of the EPS production by $A$. pullulans MTCC 2195 . The medium components, sweet potato and yeast extract, were screened to be the most significant components that influence the EPS production by PB experiment. CCD was proposed to study the interaction effects of fermentation condition. Maximum EPS production $9.3 \mathrm{~g} / \mathrm{L}$ was obtained using the optimized condition of sweet potato $10(\%)$, yeast extract $0.75(\%)$, $5.5 \mathrm{pH}$, and time $100 \mathrm{~h}$. Results of this showed that sweet potato may be used as an alternate carbon source for economical production of pullulan biopolymer.

Acknowledgments First and corresponding author wish to thank the Management and Staff of Biotechnology Department, Madha Engineering College, Kundrathur, Chennai for their support.

Conflict of interest The authors declare that there is no conflict of interest on publication of this article.

Open Access This article is distributed under the terms of the Creative Commons Attribution 4.0 International License (http:// creativecommons.org/licenses/by/4.0/), which permits unrestricted use, distribution, and reproduction in any medium, provided you give appropriate credit to the original author(s) and the source, provide a link to the Creative Commons license, and indicate if changes were made.

\section{References}

Aarthi N, Karna VR (2012) Polyhydroxybutyrate production in Bacillus mycoides DFC1 using response surface optimization for physico-chemical process parameters. 3 Biotech 2:287-296

Alok J, Abhishek DT, Tanweer A, Rajendra Y (2013) Process optimization for manufacture of pearl millet-based dairy dessert by using response surface methodology (RSM). J Food Sci Technol 50:367-373

Auer DPF, Seviour RJ (1990) Influence of varying nitrogen sources on polysaccharide production by Aureobasidium pullulans in batch culture. Appl Microbiol Biotechnol 32:637-644

Baskar G, Renganathan S (2012) Optimization of L-asparaginase production by Aspergillus terreus MTCC 1782 using response surface methodology and artificial neural network-linked genetic algorithm. Asia Pac J Chem Eng 7:212-220

Chen W, Zhao Z, Chen SF, Li YQ (2008) Optimization for the production of exopolysaccharide from Fomes fomentarius in submerged culture and its antitumor effect in vitro. Bioresour Technol 99:187-191

Cho EJ, Oh JY, Chang H, Yun JW (2006) Production of exopolysaccharides by submerged mycelial culture of a mushroom Tremella funiformis. J Biotechnol 1:129-140

Cupul WC, Abarca GH, Carrera DM, Vázquez RR (2014) Enhancement of ligninolytic enzyme activities in a Trametes maximaPaecilomyces carneus co-culture: key factors revealed after screening using a Plackett-Burman experimental design. Electr J Biotechnol 17:114-121 
De Baets S, Du Laing S, Francois C, Vandamme EJ (2002) Optimization of exopolysaccharide production by Tremella mesenterica NRRL Y-6158 through implementation of fedbatch fermentation. J Ind Microbiol Biotechnol 4:181-184

Deshpande MS, Rale VB, Lynch JM (1992) Aureobasidium pullulans in applied microbiology: a status report. Enz Microb Technol 14:514-527

Goksungur Y, Uzunogullari P, Dagbagli S (2011) Optimization of pullulan production from hydrolysed potato starch waste by response surface methodology. Carbohydr Polym 83:1330-1337

Haaland PD (1989) Experimental design in biotechnology. Marcel Dekker, New York

Kim SW, Xu CP, Hwang HJ, Choi JW, Kim CW, Yun JW (2003) Production and characterization of exopolysaccharides from an enthomopathogenic fungus Cordyceps militaris NG 3. Biotechnol Progr 2:428-435

Kim HO, Lim JM, Joo JH, Kim SW, Hwang HJ, Choi JW, Yun JW (2005) Optimization of submerged culture condition for the production of mycelial biomass and exopolysaccharides Agrocybe cylindracea. Bioresour Technol 96:1175-1182

Lim JM, Kim SW, Hwang HJ, Joo JH, Kim HO, Choi JW, Yun JW (2004) Optimization of medium by orthogonal matrix method for submerged mycelial culture and exopolysaccharide production in Collybia maculate. Appl Biochem Biotechnol 2:159-170

Manitchotpisit P, Skory CD, Leathers TD, Lotrakul P, Eveleigh DE, Prasongsuk S, Punnapayak H (2011) $\alpha$-Amylase activity during pullulan production and $\alpha$-amylase gene analyses of Aureobasidium pullulans. J Ind Microbiol Biotechnol 38:1211-1218

Mayur J, Harshad P, Shilpa G, Akshaya G (2013) Nutrient improvement for simultaneous production of exopolysaccharide and mycelial biomass by submerged cultivation of Schizophyllum commune AGMJ-1 using statistical optimization. 3 Biotech 3:307-318

Moubasher H, Wahsh S (2014) Pullulan production from Aureobsidium pullulans by continuous culture. Basic Res J Microbiol $1: 11-15$

Plackett RL, Burman JP (1946) The design of optimum multifactorial experiments. Biometrika 33:305-325
Roukas T, Biliaderis CG (1995) Evaluation of carob pod as a substrate for pullulan production by Aureobasidium pullulans. Appl Biochem Biotechnol 55:27-43

Saha BC, Bothast RJ (1993) Starch conversion by amylases from Aureobasidium pullulans. J Ind Microbiol 12:413-416

Sharmila G, Muthukumaran C, Nayan G, Nidhi B (2013a) Extracellular biopolymer production by Aureobasidium pullulans MTCC 2195 using jackfruit seed powder. J Polym Environ 21:487-494

Sharmila G, Nidhi B, Muthukumaran C (2013b) Sequential statistical optimization of red pigment production by Monascus purpureus (MTCC 369) using potato powder. Ind Crop Prod 44:158-164

Srikanth S, Swathi M, Tejaswini M, Sharmila G, Muthukumaran C, Jaganathan MK, Tamilarasan K (2014) Statistical optimization of molasses based exopolysaccharide and biomass production by Aureobasidium pullulans MTCC 2195. Biocatal Agric Biotechnol 3:7-12

Vijayendra SVN, Bansal D, Prasad MS, Nand K (2001) Jaggery: a novel substrate for pullulan production by Aureobasidium pullulans CFR-77. Process Biochem 37:359-364

Wang YX, Lu ZX, Lu FX (2004) Media optimization for exopolysaccharide by Pholiota squarrosa (Pers. Ex Fr.) Quel. AS 5.245 in submerged fermentation. Chin J Biotechnol 20:414-422

Wang Z, Quan Y, Zhou F (2014) Optimization of medium composition for exopolysaccharide production by Phellinus nigricans. Carbohydr Polym 105:200-206

Wu SJ, Jin ZY, Tong QY (2009) Sweet potato: a novel substrate for pullulan production by Aureobasidium pullulans. Carbohydr Polym 76:645-649

Xiao JH, Chen DX, Liu JW, Liu ZL, Wan WH, Fang N, Xiao Y, Qi Y, Liang ZQ (2004) Optimization of submerged culture requirements for the production of mycelial growth and exopolysaccharide by Cordyceps jiangxiensis JXPJ 0109. J Appl Microbiol 96:1105-1116

Zhou X, Cheng XJ, Liu WF, Li J, Ren LH, Dang QF, Feng C, Chen XG (2013) Optimization and characteristics of preparing chitosan microspheres using response surface methodology. J Appl Polym Sci 127:4433-4439 